ISSN (print): 0853-8301; ISSN (online): 2745-777X Available online at https://ejournal.unib.ac.id/index.php/triadik DOI: https://doi.org/10.33369/triadik.v20i1.16468 page: $26-34$

\title{
PENGARUH LAYANAN KONSELING KELOMPOK TERHADAP MORALITAS REMAJA DI SMP NEGERI 2 SEBERANG MUSI, KABUPATEN KEPAHIANG
}

\author{
${ }^{1}$ Hersi Oktaviani, ${ }^{2}$ Yessy Elita, ${ }^{3}$ Arsyadani Mishbahuddin \\ 1,2,3Universitas Bengkulu
}

Korespondensi: hersioktaviani3@gmail.com

\begin{abstract}
Abstrak
Penelitian ini bertujuan untuk mendeskripsikan pengaruh layanan konseling kelompok terhadap moralitas remaja di SMP Negeri 2 Seberang Musi, Kabupaten Kepahiang. Penelitian ini menggunakan model preeksperimental one-group pre-test and post-test design. Populasi dalam penelitian ini adalah siswa SMP Negeri 2 Seberang Musi, Kabupaten Kepahiang. Prosedur pengambilan subjek penelitian ini menggunakan teknik purposive sampling. Sampel dalam penelitian ini berjumlah 10 orang siswa. Data hasil penelitian ini dianalisis menggunakan uji $t$. Hasil yang diperoleh dalam penelitian ini menunjukkan adanya peningkatan moralitas siswa setelah diberikan layanan konseling kelompok. Hal ini dapat dilihat dari hasil pengujian hipotesis dengan hasil uji t-9,464, nilai sig (2-tailed) sebesar 0,000 $(<0,05)$, maka $\mathrm{H}_{0}$ ditolak. Dapat disimpulkan, bahwa ada pengaruh layanan konseling kelompok terhadap peningkatkan moralitas remaja di SMP Negeri 2 Seberang Musi, Kabupaten Kepahiang.

Kata Kunci: Konseling Kelompok, Moralitas remaja.
\end{abstract}

\begin{abstract}
This study aims to describe the influence of counseling group services on the morality of teenagers. This study used a pre-experimental model of one-group pre-test and post-test design. The population in this study was students of SMP Negeri 2 Seberang Musi, Kepahiang. The procedure of taking the subject of this study using purposive sampling technique. The sample in this study consisted of 10 students. Data from this study was analyzed using $t$ test. The results obtained in this study showed an increase in student morality after being given counseling group services.This can be seen from the hypothetical test results with the test results of $\mathrm{t}-9,464$, the value of sig (2-tailed) of $0.000(<0.05)$, then $\mathrm{H} 0$ is rejected. It can be concluded, that there is an increasing influence of counseling group services on the morality of teenagers in SMP Negeri 2 Seberang Musi, Kepahiang.
\end{abstract}

Keywords: Group Counseling, Teenagers Morality.

\section{Pendahuluan}

Masa remaja merupakan suatu periode penting dari rentang kehidupan, suatu periode transisional, masa perubahan, masa usia bermasalah, masa di mana individu mencari identitas diri, usia menyeramkan (dreaded), masa unrealism, dan ambang menuju kedewasaan (Kori dalam Utaminingsih \& 
Maharani, 2017: 6). Remaja sebetulnya tidak mempunyai tempat yang jelas, yang mana remaja tidak termasuk golongan anak-anak, tetapi belum juga dapat diterima secara penuh untuk masuk ke golongan orang dewasa, remaja ada di antara anak-anak dan orang dewasa, oleh karena itu remaja sering kali dikenal dengan fase "mencari jati diri" atau fase "topan dan badai" (Ali \& Asrori, 2011: 9).

Menurut Hurlock (dalam Alwi, 2011: 43), perilaku remaja terjadi berdasarkan interpretasinya pada kode moral yang dipahami melalui interaksi dengan lingkungannya. Sedangkan menurut Ibung (2009:3), perilaku sangat berhubungan dengan moral yang mana merupakan nilai (value) yang berlaku dalam suatu lingkungan sosial dan mengatur tingkah laku sehingga menjadi perilaku seseorang. Remaja yang menunjukkan perilaku sesuai dengan norma dan nilai yang berlaku, maka remaja dikatakan memiliki moralitas.

Menurut Reza (2013: 48) moralitas adalah kualitas dalam perbutan manusia yang menunjukkan bahwa perbuatan itu benar atau salah, baik atau buruk. Moralitas ditentukan berdasarkan norma dan nilai yang berlaku penilaian baik dan buruk suatu perilaku di tentukan berdasarkan norma dan nilai yang tercipta dan berlaku dalam hubungan sesama lingkungan masyarakat. moralitas bukan merupakan aturan-aturan untuk suatu tindakan, tetapi merupakan alasan suatu tindakan, Ia mengistilahkan konsep tersebut dengan apa yang disebutnya sebagai moral reasoning, moral thinking atau moral judgement (Kholberg dalam Yuniarrahmah \& Rachmah, 2014: 45). Remaja tidak akan dikatakan bermoralitas yang baik apabila remaja tidak memahami moral. Moralitas remaja yang buruk akan menimbulkan dampak bagi remaja, yaitu remaja sering melawan orang tua, membentak, berkata kasar, tidak peduli terhadap keluarga dan berbuat sesuka hatinya ketika di rumah (Waty, 2017: 12). Semua ini diakibatkan oleh merosotnya moralitas anak dan adanya hubungan antara kaburnya nilai/norma dengan penyimpangan perilaku. Pada umumnya semua ini secara langsung dan tidak langsung dipengaruhi oleh lingkungan sekitarnya. Adapun faktor yang mempengaruhi moralitas diantaranya, lingkungan keluarga, sekolah dan masyarakat (Gunawan dalam Mannan, 2017: 65). Berdasarkan penjelasan di atas dapat disimpulkan bahwa untuk meningkatkan moralitas remaja yang baik dapat dilakukan melalui pendidikan, baik pendidikan moral di lingkungan sekolah, lingkungan masyarakat, maupun di lingkungan rumah yang harus diawasi gerak gerik oleh orang tua remaja.

Berdasarkan observasi dan wawancara yang dilakukan di SMP Negeri 2, Seberang Musi Kabupaten Kepahiang, pada tanggal 02 Februri 2020 diperoleh informasi bahwa perilaku siswa banyak melakukan pelanggaranpelanggaran mengenai aturan-aturan yang dibuat sekolah dan nilai-nilai di dalam masyarakat. Ada beberapa faktor yang menyebabkan rendahnya moralitas siswa yakni banyaknya orang tua dari siswa yang sibuk bekerja di kebun, orang tua siswa biasanya pulang seminggu sekali, sebulan sekali, bahkan satu tahun sekali. Hal ini menyebabkan siswa kurang mendapatkan perhatian dan pengawasan dari orang tua. Beberapa pergeseran moral yang menjadi dampak dari kesibukan orang tua yaitu banyak siswa yang tidak patuh dengan orang tua dan melanggar peraturan di sekolah yakni siswa melakukan pelanggaran seperti mengkonsumsi miras, lem aibon, merokok, mencuri, berkelahi dan membolos. Adapun masalah yang terjadi apabila 
moralitas remaja tidak dibimbing dengan baik maka moralitas siswa akan mengalami kemerosotan yakni, remaja akan merugikan dirinya sendiri baik dari fisik maupun mental, kemudian remaja akan terus menyimpang dari segi moral yang akan menyalahi aturan dalam hukum dan norma yang ada di masyarakat (Sumara, Humaedi, \& Santoso, 2017: 349).

Dalam hal ini orang tua sangat berperan penting dalam meningkatkan moralitas remaja, karena anak maupun remaja akan mengamati berbagai perilaku yang ditampilkan secara berulang-ulang dalam keluarga, interaksi antara ayah-ibu, kakak, dan orang dewasa lainnya anak akan belajar dan mencoba menirunya dan kemudian menjadi ciri kebiasaan atau kepribadiannya (Mutiah, 2010: 86). Orang tua yang sering berinteraksi dengan remaja maka orang tua bisa mengawasi perkembangan moralitas remaja sehingga sesuai dengan nilai-nilai dan norma yang berlaku di dalam masyarakat. Sebaliknya, ketika orang tua membiarkan remaja lebih sering berinteraksi dengan lingkungan luar maka moral remaja akan terbentuk dari lingkungan tersebut. Dewasa ini banyak orang tua tidak mengetahui ataupun kurang paham mengenai moralitas dalam perkembangan moral anaknya menurut Maridya (dalam Dwiyanti, 2013: 162). Orang tua yang bekerja akan berakibat pada kurangnya waktu kebersamaan, sehingga stimulus pertumbuhan dan perkembangan pada anak/remaja akan berkurang (Ali \& Asrori, 2011: 88). Remaja yang kurang akan perhatian dan kasih sayang dari orang tua akan mengalami penurunan moralitas sehingga siswa di SMP Negeri 2 Seberang Musi, Kabupaten Kepahiang banyak melakukan pelanggaran seperti mengkonsumsi lem aibon, merokok, mencuri, membolos, dan miras, sehingga peneliti tertarik untuk memberikan layanan konseling kelompok.

Konseling kelompok adalah upaya untuk membantu individu agar dapat menjalani kehidupan dengan lebih lancar, upaya itu bersifat pencegahan, mengarahkan serta perbaikan agar individu yang bersangkutan dapat menjalani kehidupan dengan lebih baik dan mengikuti aturan dan norma masyarakat menurut Romlah (dalam Sukardiana, 2014: 2). Layanan konseling kelompok bertujuan untuk mendorong perkembangan perasaan, pikiran, persepsi, wawasan dan sikap terarah kepada tingkah laku khususnya (Prayitno, 2004:3).

Berdasarkan hal-hal yang dijelaskan di atas, peneliti tertarik untuk melakukan penelitian dengan judul "Pengaruh Layanan Konseling Kelompok Terhadap Moralitas Rmaja di SMP Negeri 2 seberang Musi, Kabupaten Kepahiang".

\section{Metode Penelitian}

Metode yang digunakan adalah metode eksperimen pola one-goup pre-test and post-test design. Penelitian ini dilaksanakan di SMP Negeri 2 Seberang Musi, Kabupaten Kepahiang, pada tanggal 5 Oktober sampai dengan 26 Oktober 2020. Populasi dalam penelitian ini adalah siswa kelas VIII dan IX SMP Negeri 2 Seberang Musi. Prosedur pengambilan subjek menggunakan teknik purposive sampling. Purposive sampling adalah teknik penentuan sampel dengan pertimbangan tertentu (Sugiyono, 2016: 124). Berdasarkan teknik tersebut, peneliti memilih kelas VIII dan XI SMP Negeri 2 Seberang Musi Kabupaten Kepahiang sebagai populasi dan akan dipilih sampel sesuai karateristik yang diinginkan. 
Penelitian ini menggunakan angket sebagai alat dalam pengumpulan data. Angket adalah seperangkat pertanyaan tertulis yang diberikan kepada subjek penlitian untuk dijawab sesuai dengan keadaan subjek yang sebenarnya (Indrayanto, 2017: 173). Dalam peneliti ini terdapat skala moralitas yang disusun dengan menggunakan skala likert dengan lima respon, yaitu Sangat Sesuai (SS), Sesuai (S), Ragu- ragu (R), Tidak Sesuai (TS), dan Sangat Tidak Sesuai (STS). Angket ini digunakan untuk mengukur tingkat moralitas siswa kelas di SMP Negeri 2 Seberang Musi, Kabupaten Kepahiang.

Dalam penelitian ini, syarat uji beda yang digunakan adalah $>0,30$. Item yang memiliki koefisien minimal 0,30 daya bedanya dianggap memuaskan, sedangkan item yang memiliki koefisien $<0,30$ dapat diinterpretasikan sebagai item yang memiliki daya beda yang rendah (Azwar, 1998: 48). Dari 64 aitem yang disebar, sebanyak 1 item dinyatakan gugur dan menyisakan 63 item angket dinyatakan valid. Uji validitas instrumen merupakan prosedur pengujian untuk melihat apakah pernyataan yang digunakan dalam kuesioner dapat mengukur dengan cermat atau tidak dengan menggunakan SPSS 22.

Untuk memperoleh reliabilitas suatu instrumen, pengujian data akan dilakukan dengan menggunakan rumus Cronchbach Alpha dengan bantuan aplikasi komputer Statistical Packages for Social Science (SPSS) versi 22.0. Uji reliabilitas dilakukan dengan cara membandingkan angka Croncbach alpha dengan ketentuan nilai Croncbach Alpha minimal adalah 0,70. Artinya jika nilai Cronchbach Alpha yang didapatkan dari hasil perhitungan SPSS lebih besar dari 0,70 maka disimpulkan angket tersebut reliabel. Hasil uji reliabilitas pada variabel moralitas diperoleh Croanbach's Alpha =0,964. Dengan demikian instrumen dapat dikatakan reliabel.

\section{Hasil dan Pembahasan}

Pelaksanaan penelitian dilaksanakan pada tanggal 5 Oktober 2020 sampai dengan tanggal 26 Oktober 2020 bertempat di SMP Negeri 2 Seberang Musi, Kabupaten Kepahiang yang berjumlah 10 orang siswa dari 86 siswa. Pada pelaksanaannya, sebelum diberikan perlakuan, siswa diberikan pre-test berupa kuesioner untuk mengetahui tingkat moralitas pada siswa. Setelah diketahui hasil dari pre-test maka terpilih sepuluh orang siswa dengan skor tingkat moralitas yang terendah yang akan diberikan perlakuan sebanyak sepuluh kali.

Tabel 1

Penentuan Kategori

\begin{tabular}{cc}
\hline Skor & Kategori \\
\hline$\geq 221$ & Sangat Tinggi \\
\hline $190-220$ & Tinggi \\
\hline $168-189$ & Sedang \\
\hline $95-167$ & Rendah \\
\hline$\leq 94$ & Sangat Rendah \\
\hline
\end{tabular}

Moralitas siswa SMP Negeri 2 Seberang Musi, Kabupaten Kepahiang sebelum diberikan perlakuan atau layanan konseling kelompok, distribusi frekuensi pre-test mahasiswa Bimbingan dan Konseling Universitas Bengkulu dapat dilihat pada tabel 2 .

\section{Tabel 2 Frekuensi pre-test Moralitas}




\begin{tabular}{ccc}
\hline Interval & Frekuensi & Persentase \\
\hline $\begin{array}{c}\text { Sangat Tinggi } \\
\geq 221\end{array}$ & 40 & $47 \%$ \\
\hline Tinggi 190-220 & 21 & $24 \%$ \\
\hline Sedang 168-189 & 11 & $13 \%$ \\
\hline Rendah 95-167 & 14 & $16 \%$ \\
\hline $\begin{array}{c}\text { Sangat Rendah } \\
\leq 94\end{array}$ & 0 & $0 \%$ \\
\hline Total & 86 & $100 \%$ \\
\hline
\end{tabular}

Hasil dari pengambilan data awal pre-test sesuai dengan tabel 2, diperoleh 40 siswa yang dikategorikan memiliki Moralitas yang sangat tinggi, 21 siswa memiliki moralitas yang tinggi, 11 siswa memiliki moralitas yang sedang, 14 siswa memiliki moralitas yang rendah, dan tidak ada siswa yang memiliki moralitas yang sangat rendah, distribusi frekuensi post-test siswa SMP Negeri 2 Seberang Musi, Kabupaten Kepahiang dapat dilihat pada tabel 3.

Tabel 3

Frekuensi post-test Moralitas

\begin{tabular}{ccc}
\hline Kategori & Frekuensi & Persentase \\
\hline Sangat Tinggi & 4 & $40 \%$ \\
\hline Tinggi & 4 & $40 \%$ \\
\hline Sedang & 2 & $20 \%$ \\
\hline Rendah & - & - \\
\hline Sangat Rendah & - & - \\
\hline Total & 10 & $100 \%$ \\
\hline
\end{tabular}

Hasil post-test pada tabel 3, temuan peneliti ini menunjukkan bahwa moralitas siswa meningkat dari rendah menjadi tinggi. Dari sepuluh siswa yang telah diberikan layanan konseling kelompok diketahui bahwa dua orang siswa memiliki kategori moralitas siswa yang sedang, empat orang siswa memiliki kategori moralitas yang tinggi dan empat orang siswa memiliki moralitas yang sangat tinggi. Adapun perbandingan skor dan mean sepuluh orang siswa yang memiliki skor rendah saat pre-test dan post-test setelah diberikan layanan konseling kelompok pada tabel 4 .

\section{Tabel 4}

Perbandingan skor pre-test dan post-test Moralitas

\begin{tabular}{cccccc}
\hline \multirow{2}{*}{ Responden } & \multicolumn{2}{c}{ Pre-Test } & \multicolumn{2}{c}{ Post Test } & Peningkatan \\
\cline { 2 - 5 } & Skor & Kategori & Skor & Kategori & \\
\hline AF & 143 & Rendah & 227 & $\begin{array}{c}\text { Sangat } \\
\text { Tinggi }\end{array}$ & 84 \\
\hline FE & 136 & Rendah & 181 & Sedang & 45 \\
\hline HE & 146 & Rendah & 221 & $\begin{array}{c}\text { Sangat } \\
\text { Tinggi }\end{array}$ & 75 \\
\hline NA & 147 & Rendah & 182 & Sedang & 35 \\
\hline RA & 163 & Rendah & 246 & $\begin{array}{c}\text { Sangat } \\
\text { Tinggi }\end{array}$ & 83 \\
\hline RI & 156 & Rendah & 203 & Tinggi & 47 \\
\hline SA & 136 & Rendah & 197 & Tinggi & 61 \\
\hline
\end{tabular}




\begin{tabular}{cccccc}
\hline TA & 156 & Rendah & 232 & $\begin{array}{c}\text { Sangat } \\
\text { Tinggi }\end{array}$ & 76 \\
\hline WI & 155 & Rendah & 203 & Tinggi & 48 \\
\hline Jumlah & 1500 & & 2087 & & 587 \\
\hline Mean & 150 & & 208,7 & & 58,7 \\
\hline
\end{tabular}

Dari tabel 4 dapat dilihat bahwa hasil skor moralitas siswa masingmasing mengalami peningkatan. Awalnya kategori moralitas siswa sebelum diberikan layanan konseling kelompok yaitu rendah. Setelah diberikan layanan konseling kelompok, kategorinya menjadi sedang, tinggi, dan sangat tinggi. Peneliti ini mendeskripsikan moralitas siswa sebelum dilakukan pemberian layanan konseling kelompok, untuk mendeskripsikan moralitas siswa setelah diberikan layanan konseling kelompok, dan untuk mendeskripsikan pengaruh layanan konseling kelompok terhadap moralitas siswa di Negeri 2 Seberang Musi, Kabupaten Kepahiang. Hasil analisis data deskriptif sebelum diberikan perlakuan, moralitas siswa tergolong rendah. Setelah diberikan layanan konseling kelompok siswa memperoleh hasil pretest siswa yang diketahui ada dua orang siswa dalam kategori sedang, 4 orang siswa dalam kategori tinggi dan ada empat orang siswa dalam kategori sangat tinggi, Dari total terdapat sepuluh siswa.

Perubahan tingkat moralitas siswa pada pre-test dan post-test dapat dilihat melalui uji paired sampel $t$ test menunjukkan hasil -9,464 dengan signifikansi $0,000 \quad(p<0,05)$ yang berdasarkan kriteria penerimaan dan penolakan hipotesis Ho ditolak dan Ha diterima, maka diperoleh hasil bahwa ada pengaruh layanan konseling kelompok dalam meningkatkan moralitas pada siswa. Hasil uji t dapat dilihat pada tabel berikut:

Tabel 5

Hasil Uji Hipotesis (Uji t)

\begin{tabular}{ccc}
\hline & T & Sig. (2-tailed) \\
\hline $\begin{array}{c}\text { Pre Test - Post } \\
\text { Test }\end{array}$ & $-30,706$ &, 000 \\
\hline
\end{tabular}

Dilihat dari tabel 5 dapat diketahui bahwa Sig. (2 tailed) sebesar 0,000 yang artinya nilai Sig. (2 tailed) lebih kecil dari 0,70 maka hipotesis (Ho) ditolak dan hipotesis (Ha) diterima. Dapat disimpulkan bahwa ada peningkatan moralitas siswa setelah diberikan treatment berupa layanan konseling kelompok.

Moralitas adalah kualitas dalam perbuatan manusia yang menunjukkan bahwa perbuatan itu benar atau salah, baik atau buruk. Remaja tidak akan dikatakan bermoralitas yang baik apabila remaja tidak memahami moral. Moral dapat diartikan sebagai pengetahuan atau wawasan yang menyangkut budi pekerti manusia yang beradab. Moral sangat terkait dengan keyakinan, baik dan buruk, diri sendiri, dan lingkungan penjelasan tersebut mengandung arti bahwa moral merujuk pada akhlak yang cocok dengan aturan yang ada pada masyarakat yang di dalamnya menyangkut adat istiadat dalam mengontrol perbuatan atau perilaku. Remaja yang menunjukkan perilaku sesuai dengan norma dan nilai yang berlaku, maka remaja dikatakan memiliki moralitas (Reza, 2013: 48). Peneliti melakukan peningkatan moralitas pada siswa SMP Negeri 2 Seberang Musi, Kabupaten Kepahiang dengan cara memberikan layanan konseling kelompok. 
Sebelum diberikan layanan konseling kelompok, sampel diambil berdasarkan hasil angket pre-test yang diberikan kepada 86 orang siswa SMP Negeri 2 Seberang Musi, Kabupaten Kepahiang. Dari hasil angket tersebut terdapat sepuluh siswa yang mempunyai moralitas paling terendah akan diberikan layanan konseling kelompok sebanyak sepuluh kali pertemuan. Sebelum diberikan layanan konseling kelompok kebanyakan siswa tidak mengetahui dampak-dampak bahaya dari pelanggaran yang dilakukkan pada saat siswa berperilaku membolos, mencuri, berkelahi mengkonsumsi miras, lem aibon, dan merokok, hal ini disebabkan kurangnya perhatian dan kasih sayang dari orang tua siswa yang sibuk bekerja di kebun.

Pada saat pertemuan pertama konseling kelompok, awalnya sepuluh siswa malu-malu untuk menceritakan permasalahannya, siswa hanya menjawab pertanyaan saat ditanya dan berani bertanya saat ditunjuk, peneliti berusaha membuat siswa percaya dan meyakinkan bahwasannya permasalahan mereka tidak akan disebar kepada siapapun. Adanya konseling kelompok ini siswa percaya dan makin terbiasa memahami tujuan dari layanan konseling kelompok, hal ini membuat siswa mulai berani, semakin akrab, terbuka untuk berbagi cerita dalam mengeluarkan pendapat, saling memberi saran saling membantu dalam memecahkan permasalahan, berbagi pengalaman, informasi sehingga setiap pertemuan menjadi semakin banyak meningkatan pengetahuan dan informasi mengenai permasalahan dari siswa. Siswa mulai berkomitmen dan berjanji untuk tidak mengulangi pelanggaran yang dilakukannya yang mana siswa mempunyai cita-cita untuk masa depannya, karena siswa ingin membahagiakan orang tuanya. Siswa mulai memahami tentang kesibukkan orang tuannya yang bekerja di kebun, sehingga manfaat mengikuti layanan konseling kelompok dapat dirasakan dan bisa membuat mereka menjadi lebih baik lagi, berfikir dalam bertindak, agar tidak melakukan tindakkan yang dapat mengecewakan orang tua..

Dalam masa kegiatan konseling kelompok siswa AF, HE, NA dan TA adalah yang paling menunjukkan kemajuan. Awalnya siswa mempunyai moralitas yang rendah, setelah diberikan konseling kelompok siswa mengalami peningkatan moralitas dalam kategori sangat tinggi. Sedangkan siswa RA, RI, SA, dan WI sebelum diberikan konseling kelompok juga menunjukkan kemajuan dari kategori rendah menjadi kategori tinggi . Kemudian siswa FE dan IQ memperoleh kemajuan dari kategori rendah menjadi sedang.

Sebelum diberi layanan sepuluh siswa memiliki frekuensi melakukan pelanggaran-pelanggaran seperti berkelahi, membolos, lem aibon, merokok, dan miras. Namun pada saat pemberian konseling kelompok sepuluh siswa mulai menyadari bahwa banyak sekali kerugian/dampak dari berkelahi, membolos, lem aibon, merokok, dan miras hal ini terlihat saat siswa menyampaikan pesan dan kesan serta mereka berkomitmen atau berjanji untuk tidak mengulanginya. sepuluh siswa ini mengaku bahwasannya dirinya sering merasa kurang perhatian dan kasih sayang dari orang tua mereka, yang sibuk bekerja di kebun, sehingga mudah sekali siswa terpengaruh dengan lingkungan sekitarnya, dan ketidak tahuannya tentang dampak-dampak dari berkelahi, membolos, lem aibon, merokok, dan miras. Sehingga AF berjanjian/ berkomitmen kepada dirinya sendiri untuk merubah kebiasaan buruknya dengan cara tidak mudah terpengaruh dari ajakan temannya, dan mulai memahami pekerjaan orang tuannya 
kemudian anggota kelompok saling memberikan dukungan agar tidak melakukan hal-hal yang negatif. Konselor memberikan contoh atau role model yang sesuai dengan kondisi sepuluh siswa, sehingga pikiran siswa menjadi terbuka untuk belajar berubah menjadi baik demi masa depannya untuk meraih cita-cita dan bisa membahagiakan kedua orang tuanya.

Dari hasil post-test siswa, semua mengalami peningkatan. Pemberian konseling kelompok dilakukan sebanyak sepuluh kali pertemuan. Anggota kelompok secara secara langsung memahami moralitas yang baik hal ini dapat dilihat dari kontrak perilaku dan komitmen dari siswa saat pemberikan layanan konseling kelompok dan dari hasil post-test. Hal ini menunjukkan bahwa setelah diberikan layanan konseling kelompok terdapat peningkatan moralias pada siswa SMP Negeri 2 Seberang Musi, Kabupaten Kepahiang.

Dapat disimpulkan bahwa ada perbedaan tingkat moralitas siswa sebelum dan sesudah diberikan layanan konseling kelompok pada moralitas remaja di SMP Negeri 2 Seberang Musi, Kabupaten Kepahiang .Hal ini menunjukan bahwa layanan konseling kelompok sangat efektif untuk meningkatkan moralitas.

\section{Kesimpulan}

Moralitas remaja di SMP Negeri 2 Seberang Musi, Kabupaten Kepahiang sebelum diberikan layanan konseling kelompok tergolong rendah, dilihat dari hasil pre-test siswa sebelum diberikan layanan konseling kelompok. Moralitas siswa setelah diberikan layanan konseling kelompok mengalami peningkatan denan rata-rata pada kategori sedang, tinggi dan sanat tinggi. Hal tersebut dapat ditunjukkan dengan adanya peningkatan pada hasil skor post-test. Adanya pengaruh layanan konseling kelompok pada siswa SMP Negeri 2 Seberang Musi, Kabupaten Kepahiang, menunjukkan perubahan signifikan adanya peningkatan moralitas pada siswa.

Dilihat dari hasil diperoleh dalam penelitian ini menunjukkan adanya peningkatan moralitas siswa yang orang tuanya sibuk bekerja di kebun pada siswa SMP Negeri 2 Seberang Musi, Kepahiang setelah diberikan layanan konseling kelompok. Hal ini dapat dilihat dari hasil pengujian hipotesis dengan hasil uji t-9,464, nilai sig (2-tailed) sebesar 0,000 $(<0,05)$, maka $\mathrm{H}_{0}$ ditolak. Maka menunjukkan perubahan signifikan adanya peningkatan moralitas siswa setelah diberikan layanan konseling kelompok

Berdasarkan hasil penelitian, maka peneliti dapat memberikan saran kepada pihak yang terlibat, pertama saran untuk sekolah yaitu Pihak sekolah bisa berkolaborasi antara guru mata pelajaran dan wali kelas atau mengundang pemateri dari luar seperti polisi. Agar bisa memberikan materi tentang moralitas sehingga remaja bisa terhindar dari hal-hal yang negatif dan remaja bisa taat terhadap peraturan. Lalu yang kedua saran untuk siswa, dengan diberikannya layanan konseling kelompok diharapkan siswa dapat memikirkan tentang masa depan agar siswa tidak berhenti menempuh pendidikan supaya cita-cita siswa bisa tercapai dan berhenti untuk melanggar peraturan di dalam masyarakat, sekolah dan keluarga. Saran terakhir yakni untuk peneliti selanjutnya yaitu hasil peneliti ini dapat berguna dan dijadikan referensi penelitian selanjutnya semoga dapat digunakan dengan sebaik-baiknya dan bermanfaat. 


\section{Daftar Pustaka}

Ali, M., \& Asrori, (2011). Psikologi Remaja. Jakarta: Bumi Aksara.

Alwi, S. (2011). Perkembangan dan Pendidikan Moral pada Remaja. Jurnal: Pencerahan Intelektual Muslim, 1(2), 42-54.

Azwar, S. (1998). Metodelogi Penelitian. Yogyakarta: Pustaka Pelajar.

Gianoza, J. (2013). Hubungan Perhatian Orangtua dengan Moral Remaja. Konselor, 2(1), 21-26. https://doi.org/10.24036/0201321734-0-00.

Ibung, D. (2009). Mengembangakan Nilai Moral Pada Anak. Jakarta: PT. Eleks Media Komputindo.

Indrayanto. (2017). Metodelogi Penelitian. Palembang: NeorFikri.

Mannan, A. (2017). Pembinaan Moral Dalam Membentuk Karakter Remaja (Studi Kasus Remaja Peminum Tuak di Kelurahan Suli Kecamatan Suli Kabupaten Luwu). Aqidah-Ta: Jurnal Ilmu Aqidah, 3(1), 59-72. https://doi.org/10.24252/aqidahta.v3i1.3408.

Mutiah, D. (2010). Psikologi Bermain Anak Usia Dini. Jakarta: Kencana Prenada Media Group.

Dwiyanti, R. (2013). Peran Orang Tua Dalam Perkembangan Moral Anak (Kajian Teori Kohlberg). Prosiding Seminar Nasional Parenting, 3(1), $161-169$.

Reza, I. F. (2013). Hubungan Antara Religiusitas Dengan Moralitas Pada Remaja Di Madrasah Aliyah (Ma). HUMANITAS: Indonesian Psychological Journal, $\quad$ 10(2), 45-58. https://doi.org/10.26555/humanitas.v10i2.335.

Sugiyono. (2016). Metode Penelitian Pendidikan. Bandung: Alfabeta.

Sukardiana, P. (2014). Konsep Dasar Bimbingan dan Konseling Kelompok (Online). Tersedia: http://putuskardiana27.blogspot.com/ , 19 November 2004.

Sumara, D. S., Humaedi, S., \& Santoso, M. B. (2017). Kenakalan Remaja Dan Penanganannya. Prosiding Penelitian Dan Pengabdian Kepada Masyarakat, 4(2), 346-353. https://doi.org/10.24198/jppm.v4i2.14393.

Utaminingsih, D., \& Maharani, C. A. (2017). Bimbingan dan Konseling Perkembangan Remaja. Yogyakarta: Psikosain.

Prayitno. (2004). Seri Kegiatan Pendukung L1-L9. Padang: Universitas Negeri Padang.

Waty, A. (2017). Hubungan Interaksi Sosial Dengan Perkembangan Moral Pada Remaja Di SMA UISU Medan. Psikologi Konseling, 10(1), 11-24. https://doi.org/10.24114/konseling.v10i1.9629.

Yuniarrahmah, E., \& Rachmah, D. N. (2014). Pola Asuh Dan Penalaran Moral Pada Remaja Yang Sekolah Di Madrasah Dan Sekolah Umum Di Banjarmasin Parenting and Moral Reasoning of Adolescent in Madrasah and Public School in Banjarmasin. Jurnal Ecopsy, 1(2), 43-50. 